\title{
ARTICLES
}

\section{ISLAMIC CIVILISATION AS A GLOBAL PRESENCE WITH SPECIAL REFERENCE TO ITS KNOWLEDGE CULTURE}

\author{
Osman Bakar*
}

\begin{abstract}
The main aim of this article is to discuss the meaning and characteristics of Islamic civilisation and its global presence, particularly in the field of knowledge culture. Since both terms have been contested in contemporary scholarship to the point of their critics denying epistemic legitimacy to the concept of Islamic civilisation itself, the article devotes a lengthy discussion to defending its continuing validity and legitimacy. The most serious challenge comes from the concept of world-system developed by a number of Western thinkers, especially Immanuel Wallerstein. The article also explains the meaning of a civilisation's global presence, which it argues exists at three different levels, namely territorial presence, cultural presence, and intellectual-spiritual presence. It argues that in the case of Islamic civilisation, its global presence exists at all the three levels. Since knowledge culture is presented as the very heart of Islamic civilisation given the fact that Islam claims to be the religion of knowledge, the article provides an introductory discussion of some important aspects of knowledge culture originating from Islamic civilisation that have become accepted through the West as integral parts of our common modern civilisation. The article concludes with suggestions for further studies and research on the theme of Islamic civilisation's global presence but from new perspectives in the light of new realities in intercultural and inter-civilisational relations.
\end{abstract}

\section{The Meaning and Characteristics of Islamic Civilisation}

There are three key terms in the title of this article that need explanation. These terms are "Islamic civilisation," "global presence," and "knowledge culture." Accordingly, this paper commences with an explanation of each of these terms, albeit briefly. As for the term "Islamic civilisation," it is by no means a universally favoured one. In our own times, this term is increasingly becoming a deeply contested one among scholars of world cultures and world history, including those specialising in Islamic thought in general and in Islamic cultural history in particular. The reason for this contestation is that the two component words in the term, namely "civilisation" and "Islamic," have both become highly contested. Many Western academics, particularly in North America due to cultural, intellectual, and political factors peculiar to that part of the world, have disowned the word "civilisation" in favour of the word "world-system." 
Despite this contestation, we prefer to maintain the use of the term "Islamic civilisation" rather than the term "Islamic world-system," since meaning-wise the word civilisation would be a better English rendering of the technical Arabic terms for the largest and most developed cultural organism than the latter word. ${ }^{2}$

Since the arguments against the use of the word civilisation have a wide appeal, we feel it is necessary to address them to show that they do not apply to the Islamic understanding of civilisation and the Muslim historical experience in civilisation-building. In the several pages that follow, we provide a comparative discussion of the Muslim and Western notions of civilisation and their historical experiences in civilisation-building. We also provide arguments why the idea of world-system could not be considered as a good substitute for the notion of civilisation. We fully understand the underlying reason behind the change in terminological usage from civilisation to world-system that has been brought about by a large segment of the Western academic community. As seen by its critics, many of whom are postmodernists, the word "civilisation" as understood in the West carries with it a number of value-laden connotations such as superiority, civility, and humanness, which has been used in its past to justify the West's racism, imperialism, colonialism, coercive acculturation, and even genocide in its treatment of non-Western peoples, cultures, and societies.

In other words, in the West the term civilisation carries a historical baggage that had accumulated over the last few centuries as a result of its long turbulent ties with the rest of the world, notably the Islamic world. The main components of this historical baggage are intellectual, religious, and political in nature. Non-Westerners would generally agree with the postmodernists' critique of the widely prevailing misconception of civilisation in modern Western intellectual history that found unfortunate applications in its colonial policies only to produce a destructive impact on the rest of the world. However, many of them would not agree with the suggestion that in the light of pejorative meanings that had been given in the West to the term civilisation with disastrous consequences for non-Western cultures and societies the term itself should be discarded from the English vocabulary. What needs to be done is not discarding but correcting it.

Erroneous views of civilisation especially that are collective in nature and that can easily lend themselves to translations into disastrous public policies as were to prevail in the modern West need to be first identified and then corrected. It does not serve any purpose if collective errors are duly acknowledged but then sought to be forgotten by erasing the word civilisation from the collective memory. Intellectual honesty requires the collective erroneous views of civilisation to be squarely confronted by identifying their causes and then preventing them from surfacing again. Substituting the word civilisation with the term world-system or whatever other word one may think of is no guarantee that past civilisational 
errors would not be committed again. In fact, if we examine closely the Western initiated concept of world-system now in currency mainly in the disciplines of world history and political economy we find that the previous mistake of universalising the West's particular and limited civilisational experience is again being repeated.

The world-system theory and analysis is developed almost exclusively on the basis of European history, its modern civilisational traits, and the transformation of its economic systems. Again the historical experiences of other cultures and civilisations are largely ignored, especially the Islamic civilisation, which perhaps provides the best case for comparison and contrast with the West by virtue of their long history of mutual influence. Islamic civilisation was both a worldempire and a world-economy. It was certainly a world-system according to the criteria set forth by its theorists, but it was more than just a world-system. Critics of the concept of world-system rightly characterise it as primarily an economic organism with a poor cultural content. To reduce Islamic civilisation - indeed any spiritually-based civilisation - to a world-system so conceptualised is to empty it of its rich spiritual, intellectual, and cultural content.

If the West is to prevent its past civilisational errors from resurfacing in its societies, regardless of whether in the same old forms or in new ones, with all their consequences for the global community, then it is called upon to enter into a truly meaningful multidimensional inter-civilisational dialogue, which so far it has largely shunned. ${ }^{3}$ The West ought to realise that its historical baggage insofar as its treatment of other cultures and civilisations is concerned is too heavy an intellectual burden to be unloaded and resolved by its collective mind alone, at least certainly not in its present shape and form and philosophical orientation. ${ }^{4}$ The issue at hand is profound and complex, interwoven as it were with so many other fundamental issues of "civilisational" proportions, especially the intellectual, political, and religious. If this issue is to be resolved, then the West needs an input from the non-West.

It may be further argued that the reality of our contemporary world makes it an imperative for both parties to cooperate with each other in addressing the issue. Thanks to the impactful globalisation of people, cultural goods, and ideas, the increasingly pluralistic nature of Western societies as well as the growing interdependence of the constituent regions of our global community have helped to transform this civilisational issue into a common issue for all humanity. This issue, therefore, ought to prominently feature in contemporary dialogues of cultures and civilisations. It requires thoughtful responses from their advocates and participants if our common human civilisation is to survive, let alone to flourish on a solid and sound foundation. Moreover, any study of comparative civilisation worthy of the name, particularly one that would include dealing with 
civilisational relations between Islam and the West, would have to confront the issue inasmuch as it is of a major significance to our common future. However, the scope of this article does not allow us to go into a deeper discussion of the intricacies of the Western historical baggage that are tied up to the usage of the word "civilisation."

In arguing for the continuing validity and legitimacy of the word "civilisation," we maintain that the Muslim usage of it is epistemologically sound, being in full accord with the philosophical idea of cultural species that is pluralistic and diverse in nature and with the indisputable historical fact of diverse civilisational experiences of the different branches of humanity. In our view, aside from the historical baggage argument, which is not intrinsic to the nature of civilisation, many strong arguments, including philosophical and scientific, might be advanced against discarding the word "civilisation" in favour of the term "world-system." True enough, as asserted by its theorists, the conception of world-system retains a good number of the traditional features of civilisation. Like a civilisation, a world-system is viewed as a cultural organism having phases of growth and a lifespan. In his definition of world-system earlier quoted, Wallerstein described it as having "the characteristics of an organism, in that it has a lifespan over which its characteristics change in some respects and remain stable in others." ${ }^{5}$ However, in sharp contrast to traditional civilisations that are generally rich in cultural and spiritual contents, of which Islamic civilisation is an excellent living example, a world-system appears as a culturally impoverished cultural organism. As such, a world-system cannot aspire to be in the rank of cultural species called civilisations. Moreover, lacking a worldview which usually functions as the soul of a civilisation, including of the materialistic type, a world-system is found to be analogous to a body without a soul.

In the following brief exposition of the Islamic idea of civilisation we may see both its similarities and its differences with the concept of world-system. The idea of civilisation as constituting a particular cultural species has its basis in the Qur'an. The key term in the Qur'an pertaining to this idea is ummah, which appears in its text more than seventy times in different contexts and with different connotations. This word conveys the core meaning of an organised community that is governed by certain laws, usually divine. In one verse, the Qur'an describes the animal species as forming communities (umam, plural of ummah) similar to human communities. ${ }^{6}$ This verse permits us to speak of ummah as a genus of living organisms comprising two species, namely animal species in the natural world and cultural species in the human world. ${ }^{7}$ By cultural species is meant a human community together with the cultural environment it has created. There are many different cultural species inasmuch as there are human communities with different sizes, belief systems and worldviews, diversity patterns, both ethnic 
and religious, and depths and breadths of cultural achievements. Therefore, in the perspective of the Qur'an, cultural species is akin to animal species, having as it were many similarities with the latter.

As a member of a particular cultural species, a culture is a living organism in the human world in much the same way each member of an animal species is a living organism in the natural world. Both animal and cultural species exist in different sizes, shapes, and forms and they have also different life-spans. ${ }^{8}$ Moreover, they are subject to different laws with the animal species being governed by natural biological laws and cultural species by societal laws. ${ }^{9}$ We thus have many kinds of cultural species in the human world, ranging in size and complexity from the smallest and simplest to the largest and most complex and the most sophisticated of them.

Both in terms of physical size and organisational complexity, the smallest and simplest cultural species is the human family, which itself admits of several sub-species. ${ }^{10}$ The largest and most complex of cultural species is what we call civilisation just as the largest animal species to have ever lived on earth but now extinct is identified, at least in the popular imagination of modern man if not in real natural history, with what are called the dinosaurs. In between, we have intermediate cultural species such as villages, towns, cities, states, kingdoms, sultanates, caliphates, and empires. A civilisation is larger in territorial size and scope of its cultural manifestations and deeper in cultural complexity and sophistication than each of these cultural units. Moreover, as it often does, a civilisation may even embrace all of these cultural units together.

As for Islamic civilisation viewed as a whole as one single cultural entity, there were times in its history when it comprised all at once the most advanced towns and cities in the world and powerful caliphates and sultanates rivalling each other in material prosperity and cultural brilliance. Moreover, like any other civilisation Islamic civilisation is not merely an aggregate of territorial categories such as towns, cities, and kingdoms. It is also a combination of all organised human activities in all fields of life and thought such as religion, politics, education, economics, commerce and trade, science and technology, and art and literature as necessitated by collective human living. However, Islamic civilisation understood in this comprehensive sense may be seen as possessing a distinct identity, notwithstanding the many similarities it shares with other civilisations. It is also seen as having several major branches, ${ }^{11}$ each of which being often referred to and treated as a civilisation in its own right. In other words, each of these branches of global Islamic civilisation has an identity of its own that distinguishes it from the other branches. One such branch is Malay-Islamic civilisation that has its territorial base in the Malay Archipelago. ${ }^{12}$ The word "civilisation" is indeed frequently applied to Malay-Islamic culture in its totality. 
That a branch of a civilisation is also qualified to be viewed as a civilisation in its own right raises the fundamental question of what constitutes its essential characteristics. In attempting to answer this question it is perhaps pertinent to observe the following point about civilisations. A civilisation is not an arbitrary and artificially created cultural unit that lacks commonalities, coherence, and underlying unity of its diverse components. On the contrary, despite its incomparable physical size and the great diversity in its constitution a civilisation displays an underlying unity that befits its treatment as a unique cultural organism. However, far more essential than physical or territorial size as features of civilisation are coherence in worldview, richness in diversity, clear presence of one or more unifying principles, and comprehensiveness of cultural achievements. We will now show that, on the basis of Islam's more than fourteen centurieslong civilisational experience, it is possible for the essential characteristics of a civilisation existing on a global scale to be also possessed in full by its branch at a regional level, which constitutes a much smaller geo-cultural entity, territorially speaking, thus enabling the branch to be also considered as a civilisation. In terms of cultural achievements, however, it could very well be that a branch of a civilisation outshines the rest of it.

Islamic civilisation is noted for having a simple, coherent, and crystal clear worldview. The core content of its worldview is the principle of unity (tawhìd) and its manifestations at all levels of cosmic and microcosmic existence, the latter to be understood as referring to both individual and collective human existence. In religious terminology, this core content is none other than the six articles of faith (arkān al-imān), which every Muslim must believe in, combined together with the five pillars of Islam (arkān al-isläm), which he or she must perform. Hence, in Islam, individual and collective core beliefs and actions coincide, thereby enabling its civilisation to attain a degree of unity unmatched by any other civilisation. The principle of tawhid is embodied in the twin testimonies of Islamic faith, namely the unity of God and the apostleship of Muhammad (salutation and peace be upon him). Thus, it has been said, and rightly so, that Islamic civilisation is founded on the first pillar of Islam as collectively understood and experienced by the Muslim community (ummah). Islamic civilisation in its entirety may indeed be viewed as the Muslim ummah's collective witnessing of the unity of God and the apostleship of Muhammad (salutation and peace be upon him). Another way of looking at Islamic civilisation is to visualise it as the total expression of Muslim collective worship ( $i b \bar{a} d a h$ ) in all domains of life. ${ }^{13}$

Islamic civilisation is also said to be based on the remembrance of God (dhikr'Allāh), ${ }^{14}$ which may be understood as the very spirit that is breathed into its body, permeating the whole of it and thereby refining and furnishing it with quality (ihsān). In Islamic perspectives, civilisation is about the art and quality of 
collective living, not about its material content as emphasised in the modern idea of material progress, although material prosperity is by no means excluded from the list of man's civilisational achievements. The quality of life at all levels and in all domains - individual, collective, and civilisational - is essentially determined by the quality of man's remembrance of God understood in its comprehensive sense. ${ }^{15}$

It is to be noted that the foundational principle of Islamic civilisation and its ultimate earthly goal are one and the same, namely the principle of tawhìd. However, there is an important difference in one respect between the principle in serving as a foundation or point of departure for collective human actions and the principle in serving as their ultimate goal. In the spiritual and intellectual journey from the departure point to the destination point there is supposed to be a qualitative improvement in one's understanding, appreciation, and other facets of internalisation of the principle of tawhi $d$. There is the strong expectation that with a progressively richer and richer civilisational experience the reality of tawhìd will be displayed to the human mind with greater clarity. This is the real meaning and purpose of civilisational progress. Otherwise, as the Qur'an says, life on earth will be mere idle sport and play. ${ }^{16}$ For this reason, it becomes the vocation of Islamic civilisation to display unity to the greatest extent possible in all of its manifestations in human life and thought. To a certain extent Islamic civilisation succeeded in realising this mission. It is not without basis when serious students of Islamic civilisation describe unity as its hallmark.

The foregoing discussion on the four essential characteristics of civilisation clearly show that in the case of Islamic civilisation the coherence of its worldview and the clarity of its display of unity made possible by the integrating and unifying power inherent in the principle of tawhīd are unmatched by other civilisations. These civilisational features are in sharp contrast to the lack of a coherent worldview and the inner tension and conflict that characterise world-systems. All major branches of Islamic civilisation possess these two characteristics displaying them to varying degrees of intensity. However, for historical reasons, each branch has particularised Islam's essential and universal worldview. The Malay-Islamic world has particularised it through its adoption of Ash'arite theology, which is a particular interpretation of the universal principle of tawhid, just as another branch of Islamic civilisation has particularised it by adopting another school of theology in the interpretation of tawhìd. The particularised worldview remains coherent and Islamic. The Malay-Islamic world was also able to attain a visibly high degree of cultural unity thanks to its common theology, common law, common political system, and common lingua franca. ${ }^{17}$ However, this cultural unity was to be shattered by the deliberate fragmentation of the region by rival European colonial powers. 
Islamic civilisation also exhibits the other two essential characteristic of civilisation - rich diversity and cultural brilliance - in a very clear manner. It was and still is rich in ethnic and religious diversity. When Islamic civilisation was at the peak of its territorial expansion the majority of the world's ethnic and religious groups had lived under its umbrella. The Muslim ummah, which was its backbone and principal creator, was itself multi-ethnic. Non-Muslim religious groups who lived as minorities under Islamic rule made a significant contribution to the creation of Islamic civilisation. How Islam engaged itself with the phenomenon of religious diversity within the boundaries of its rule and governance was itself an important facet of its civilisation. When we come to the Malay-Islamic world we also encounter a rich ethnic and religious diversity. Although Islam is the predominant religion in the region, all the other major religions of the world have followers in varying sizes. The region has a rich religious history, having been exposed to significant influences from Hinduism, Buddhism, Islam and Christianity during different periods of its history. Insofar as ethnic diversity in the region is concerned although its peoples may be lumped together under the Malay racial or ethnic stalk this race is found to have branched out into numerous ethnic and sub-ethnic groups. However, as earlier asserted, Islam was able to create unity out of this ethnic diversity through its unifying instruments, namely a common theology, a common law, a common political system, and a lingua franca.

Various facets of the past cultural brilliance of Islamic civilisation have been well documented by historians and scholars of Islamic studies. These facets pertain to the arts and the sciences and literary output of various genres. In speaking of cultural achievements understood comprehensively, however, it is important to point out that Islam's emphasis in civilisational achievement is on holistic development, especially one that is characterised by balance and moderation. The Muslim ummah is described in the Qur'an as a balanced and moderate community (ummatan wasatan). ${ }^{18}$ Despite its failings to always live up to the ideals and expectations of the Qur'an, balance and moderation has been clearly stamped on the character of traditional Islamic civilisation. Whether in the pursuit of spiritual life or material development, Islamic civilisation has largely succeeded in charting "a middle path." In the Islamic perspective, the ideal civilisation should also be holistic, balanced and moderate. For this reason, Islamic civilisation has generally shunned the excessive pursuit of material wealth and physical development at the expense of spiritual and moral development.

Many Muslims are critical of modern Western civilisation because of its excessive pursuit of material wealth and unbalanced development. In our view, there were two major intellectual errors committed by nineteenth-century Western thinkers who dwelt on the idea of civilisation and the meaning of the civilisation- 
construction. Their first error was in making the idea of material wealth and prosperity as the core defining element and characteristic of civilisation and also of progress. The modern Western idea of progress was conceived primarily in terms of material development and prosperity together with the scientific and technological achievements that make it possible. The rapid spread of this idea henceforth was not at all surprising given the fact that intangible forms of progress, especially the spiritual one, have been increasingly marginalised to the periphery of modern Western intellectual thought. From the perspective of Islamic civilisation, however, to reduce development to its economic dimension and then to further reduce this economic dimension to its material and quantitative aspects would be to go against the principle of tawhi $\bar{d}$, which is at once its very foundation and goal.

Their second error was to view physical time as having the intrinsic property to devalue past civilisational values. In other words, they saw the passage of time as necessarily rendering a loss to the worth of human cultural achievements and human values of bygone eras. A corollary of this error, which is in contradistinction to the first, is the idea of physical time as having a positive intrinsic property of conferring necessary goodness and worthiness to things that are yet to come. These thinkers and their intellectual descendants in the different continents fervently believe in the idea of progress as being inherent in the nature of time and as being achievable without the need for recourse to God and religion.

Interestingly, the idea of the twin faces of time understood as referring to its potentials both to be a source of gain and a source of loss to man, depending on how one consumes it, is found in the Qur'an itself. In one of its shortest chapters in which God swears by time the Qur'an says: "By time! Verily man is in a state of loss (khussr) except those who believe and do righteous works and who counsel each other on the Truth (al-haqq) and on the attribute of patience $\left(a l\right.$-sabr)." ${ }^{\prime 19}$ This message of the Qur'an about the nature of time is clearly the very opposite of the belief espoused by advocates and proponents of modern secular civilisation. While the Qur'an appeals to human living in accordance with supra-temporal truths and values, of which spiritual faith ( $\bar{\imath} m \bar{a} n)$, righteous works ('amal șăliḥ), subscription of the Truth (al-haqq), and nurturing the virtue of patience (sabr) mentioned in the chapter are supreme examples, as means of escaping from the state of loss incurred by the passage of time, the latter believe that time will be on man's side if he opts for a collective life and thought that is totally bound to the physical world. Gradually but surely, so their argument goes, with the help of science and technology that can only progress time will unravel the riddles and mysteries of human life and the universe. Man has no need for recourse to God and religion, because his collective ingenuity is alone viewed sufficient to help him chart an indefinite progress in his civilisation-construction. 
Modern civilisation may thus be described as a civilisation that is founded on the forgetting of God.

Although Islam's idea of civilisational achievements is founded on spiritual principles it has not prevented its civilisation from achieving cultural brilliance even by worldly standards. Since the guiding principles in its ummatic development are the same the Malay-Islamic world's cultural achievements too are holistic, balanced and moderate in nature. Malay-Islamic culture as a whole, which spans all domains of collective living, is the fruit of a creative wedding between Islam's revealed principles and Malay ethnic genius. Considering that all the essential characteristics of Islamic civilisation viewed as a global cultural entity are also possessed by Malay-Islamic culture, as clearly demonstrated in the foregoing pages, the latter deserves to be treated as a full-fledged civilisation with an identity of its own that distinguishes itself from the other branches of Islamic civilisation. Our discussion of the essential characteristics of Islamic civilisation also go to affirm not only the epistemic legitimacy of the concept of civilisation and even its superiority to the concept of world-system but also the Islamicity of Islamic civilisation.

Since the principle of tawhìd is the foundation as well as the ultimate goal of Islamic civilisation it is conformity to this principle itself that may be taken as the most fundamental criterion of the Islamicity ${ }^{20}$ of any civilisational activity or product created not just by Muslims but also by the rest of mankind. As asserted by Nasr, “...the idea of Unity (al-tawhīd) overshadows all others and remains at every level of Islamic civilisation the most basic principle upon which all else depends." ${ }^{21}$ Accordingly he adds, "The formula of Unity is the most universal criterion of orthodoxy in Islam; that doctrine may be said to be Islamic that affirms this unity in one way or another." ${ }^{22}$ In the light of this most universal criterion of the Islamicity of things, we may assert that over the greater part of its history the civilisation Muslims had created was Islamic in character regardless of the borrowings made from other civilisations and which Arabic term was used for it. Further, we wish to emphasise here that the whole lengthy foregoing discussion on the meaning and characteristics of Islamic civilisation is necessary as a prelude to the following discussion on the meaning of its global presence in world history.

\section{The Meaning of the Global Presence of a Civilisation}

The idea of a civilisation's global presence may be understood at least at three different levels. First, at the physical level but limited to its territorial base. Second, at the cultural level but confined to its tangible dimension. Third, at the intellectual-spiritual level, which pertains to intangible things such as ideas, concepts, theories, worldviews, values, and moral goods. What the first level 
means is that every civilisation has a territorial base. It is possible for a civilisation to have a limited territorial base that cannot in any way be considered as global in scale but whose culture commands a global presence. A good example is Japanese civilisation. Its territorial base is limited to the islands collectively known as Japan. In modern times, Japanese people are also found outside Japan with significant numbers in Hawaii and several Latin American countries, especially Peru. Even when we include these Japanese communities outside Japan as part of the contemporary Japanese civilisation, on the assumption that they continue to contribute to a distinctively Japanese culture, the territorial base is still limited. In cultural terms, however, modern Japanese civilisation commands a global presence through the globalisation of its cultural goods and to a lesser extent its intellectual goods. Being a technocratic society, the global presence of modern Japanese civilisation takes mainly the form of technological goods it produced and globalised for which it is world famous.

In the case of Islamic civilisation, however, its global presence exists at all the three levels that we have mentioned. Since the beginning of the eighth century, less than a hundred years after the death of the Prophet, Islam's territorial base has become global. By this we mean that territories under Islamic rule had covered the greater part of the globe, since these had extended to all the continents except the Americas. Spain was under Islamic rule for nearly eight centuries, from the first half of the eighth century to the end of the fifteenth century when it was reconquered by the Christians. Except for the loss of Spain and Sicily in Italy, Islam's territorial base has remained unchanged to this day. In terms of the Muslim demographic presence, however, the modern Muslim ummah has become truly global, since Muslim communities are found in practically every modern nationstate. It remains to be seen whether the worldwide Muslim minorities will have any significant impact on the cultural and intellectual dimensions of the future global Islamic civilisation.

The global presence of Islamic civilisation at the cultural and intellectual levels has been widely acknowledged, at least in the academic community, even though much remains to be studied. Classical tangible cultural goods, including agricultural goods, produced by Islamic science, technology, and art were globalised to the whole world, including the Americas, because these goods were either novel or the best of their kinds in their times. These cultural goods are analogous to the modern day technological products produced by the advanced countries and then exported worldwide. When Spain and Portugal conquered and shared South America between them they brought with them cultural goods that had originated from Islamic civilisation, since they were themselves part of that civilisation for centuries. However, far more enduring as facets of Islamic civilisation's global cultural presence than these physical cultural goods are the 
intellectual goods, including the intangible dimension of knowledge culture that Islam has created. Many ideas, concepts, values, and institutions originating from Islam have passed to the West through various channels and become accepted as parts of modern Western culture. Several Western scholars of Islamic civilisation, including the British Marxist historian J. D. Bernal and the Italian Assendro Bausani maintained that Islamic intellectual culture is an important integral component of modern Western culture. ${ }^{23}$ In this article we are mainly interested in the global presence of Islamic civilisation in the specific area of knowledge culture.

\section{The Meaning of Knowledge Culture}

From the point of view of the science of civilisation, ${ }^{24}$ there is no other concept that is more fundamental than the idea of knowledge culture. By "knowledge culture" we mean the same thing as "culture of knowledge." We also mean by it "scientific culture," but we do not understand the word "scientific" in the same sense as the modern one, which is known to limit its meaning to a particular type of study, method, explanation, and proof. Rather, we understand the word "scientific" in the sense of 'ilmi as understood in traditional Islamic epistemology or theory of knowledge. If we understand "scientific" as in the modern sense, then what we call knowledge culture would constitute a far wider domain of human thought and knowledge activities than scientific culture.

Due to its centrality, the knowledge culture of a particular civilisation may be viewed as its heart. This is especially true in the case of Islamic civilisation, since Islam claims to be a religion of knowledge. A knowledge culture comprises many elements, the most fundamental of which is epistemology. The foundational element of any knowledge culture is its epistemology, which may also be termed its vision of knowledge. Every civilisation is guided and shaped by its primary and dominant vision of knowledge, which constitutes the essence of its "worldview." Epistemology deals primarily with definitions of knowledge, its nature and characteristics, its sources - the most important of which is divine revelation - why and how man is able to know, and the purposes of knowledge. It also deals with the organisation, categorisation, and classification of knowledge. ${ }^{25}$ The more developed and the more advanced a civilisation and its knowledge culture become, the more refined and sophisticated will be its systematisation of knowledge in conformity with the intellectual and rational needs of the cultivators of that knowledge culture.

The other elements of a knowledge culture include its modes of transmission of knowledge to future generations, its institutionalisation of knowledge for the purposes of realising its sharing through dissemination, its knowledge ethics which pertains to its guiding ethical-moral principles in knowledge applications, and its growth and advancement through adequate and proper planning. 
Institutionalisation of knowledge needs instruments, the most basic of which is of the technological type. Institutionalisation of teaching methods, transmission and dissemination of knowledge and knowledge sharing in general, and applications of knowledge, all of these would only be effective if backed by technology that is appropriate to the needs of society. Technology thus has a very important role to play in a knowledge culture. All these various aspects and features of a knowledge culture will help us to understand how important and central it is to such a civilisation as Islam.

\section{The Global Presence of Islamic Knowledge Culture}

At the heart of Islamic civilisation, its knowledge culture appears to be its most significant dimension. Its universality and its importance to the life of every community and nation makes it easily accepted by other cultures and civilisations. Initially, the greater part of Islamic knowledge culture, including its epistemology, found acceptance in the medieval and modern West, but later on during the modern period some of its features common to both Islam and medieval Christianity were discarded in the wake of the intellectual criticism of religion in general. For example, the Latin West accepted the idea of hierarchy of knowledge, the marātib al- ulüm of Islamic epistemology, ${ }^{26}$ but during the later modern period it is no longer accepted. Similarly, in the pre-modern West many of its educated citizens were still talking about cerebral knowledge ${ }^{27}$ and cardiac knowledge ${ }^{28}$ and the need for these two types of knowledge to be balanced in human thought as insisted in Islamic civilisation. However, modern Western knowledge culture came to develop in a certain direction to the point of being obsessed with cerebral knowledge and cerebral intelligence almost to the total exclusion of cardiac knowledge and cardiac intelligence. To the extent that the modern West wholly devoted its attention to the development of its rational knowledge culture it was actually pursuing an intellectual tradition that had its roots in the Islamic knowledge culture.

On the whole, through the West, it was in the field of educational and knowledge institutions and scientific culture that Islamic civilisation found a lasting global presence. Islam founded the modern educational institutions such as universities and colleges and teaching hospitals and their academic traditions such as organisation of academic disciplines, graduation, and Professorial chairs. It founded scientific and research institutions and introduced scientific practices and norms and rational values that have become accepted practice in our modern and contemporary world. It is true, however, that the Islamic origin of all these institutions and practices is still little known to the general public, not only nonMuslim but also Muslim. The empirical tradition in our studies of both the natural and human worlds again has its origin in classical Islamic knowledge culture. 
Even more important than all of these knowledge institutions and practices is the very appreciation of knowledge in human life itself in our modern world. There is no doubt that more than any other religion or civilisation Islam has helped man to look at knowledge from a new perspective and with a new significance not found in its preceding cultures and civilisations.

\section{Policy Recommendations}

- Since knowledge of the global presence of Islamic civilisation is important to the promotion of mutual understanding among Muslims and non-Muslims worldwide but is still little known to the general public there is a need to disseminate the available knowledge on the subject as widely as possible. Muslim organisations and institutions have a role to play in this task of dissemination.

- Studies in Islamic civilisation are becoming popular in many Muslim countries where several of their universities have established centres and faculties to teach and research on the subject. Since much is still to be studied and investigated about the subject, Muslim academics and scholars have a duty to undertake research not only on the subject of Islamic civilisation itself but also its interface with other civilisations.

- They are also called upon to produce a new generation of Muslim academics and scholars who are not only knowledgeable in this field but also creative enough to draw the important consequences of their research findings for the rest of the world.

\section{Notes}

* Osman Bakar is currently Chair Professor and Director of Sultan Omar Ali Saifuddien Centre for Islamic Studies (SOASCIS), Universiti Brunei Darussalam. He may be reached at osman.bakar@ubd.edu.bn .

1. Critics of the word civilisation disagree among themselves on the best word to replace it, but the term world-system appears to be the most favoured one since in its essential features it is the closest in resemblance to civilisation. The idea of world-system was first introduced and developed in the early 1970s by such thinkers as Immanuel Wallerstein, Samir Amin, Andre Gunder Frank, and Giovani Arrighi. Wallerstein defined world-system as "... a social system, one that has boundaries, structures, member groups, rules of legitimation, and coherence. Its life is made up of the conflicting forces which hold it together by tension and tear it apart as each group seeks eternally to remould it to its advantage. It has the characteristics of an organism, in that it has a life-span over which its characteristics change in some respects and remain stable in others..." See Immanuel Wallerstein, The Modern World-System (New York: Academic Press, 1974), 347. 
2. The three most widely used Arabic terms for civilisation are tamaddun, hadāarah, and 'umrān.

3. Interfaith dialogues among Jews, Christians, and Muslims both in the West and in the Islamic world are numerous, and with a very few exceptions these dialogues are initiated by private groups and non-governmental organisations. However, inter-civilisational dialogues between centres of power and governmental institutions in the West and the Islamic world are almost non-existent.

4. The present Western collective mind is torn apart between two contending forces, namely modernism and postmodernism. Upon the collapse of its scientific worldview around the middle of the $20^{\text {th }}$ century, modernism lost its intellectual appeal and influence, conceding much of its socio-cultural space to the latter. Although postmodernism acknowledges the fact that our global community is multicultural and multi-civilisational in nature and that there are other models of civilisation-building besides the Western one, it does not have a comprehensive and coherent worldview that would enable it to provide a cogent justification for the necessity and wisdom of such a pluralistic world. Consequently, the postmodern Western mind is hardly in a position to correct past errors in the West's judgment and treatment of non-Western cultures and civilisations and thereby to bring about a civilisational reconciliation between them despite its ongoing efforts at realising "political correctness" in multicultural living.

5. See our note 2 .

6. The Qur'an, surah 6, verse 38.

7. Although in popular Muslim message the word ummah conveys the very restricted meaning of the community of Prophet Muhammad (salutation and peace be upon him!) and his followers, the Qur'an allows us to use it not only in reference to other religious communities but very significantly even to the animal species.

8. The idea of cultural species as having lifespans of their own is to be found in the Qur'an. Says the Qur'an: "For every ummah is a lifespan (ajal): when their lifespan is reached, not an hour can they cause delay, nor [an hour] can they advance [it]" (surah 7, verse 34). Some animal species such as tortoises are known to live much longer than many other species. Similarly, in the human cultural world, spiritually-based civilisations are known to exist longer than materialistic civilisations. If we may identify the life-span of a civilisation with the lifespan of its dominant worldview then modern Western civilisation founded at the beginning of the seventeenth century and shaped and sustained by the Newtonian scientific worldview may be viewed to have met its death around the middle of the twentieth century when this worldview was buried in the dustbin of Western intellectual history. This view was at least shared by the ideologues of postmodernism, which is still in search of a common worldview for its diverse ideological factions. With a life-span of just about 350 years modern Western civilisation became the shortest lived in the history of human civilisations. Its offshoot, the Communist ideology and polity founded on the worldview of scientific materialism lasted only three-quarters of a century, which in civilisational terms is as brief as the twinkling of an eye.

9. In the Islamic perspective, both natural laws prescribed for plant and animal species and societal laws that are embodied in the Shari 'ah have a common metaphysical source, namely God and, therefore, could not be opposed to each 
other. Muslim philosophers refer to natural laws discovered by science as nāmūs al-khilqah ("laws of creation") and societal laws revealed to the Prophets as nāmuss al-anbiyā' ("laws of the Prophets"). For a brief discussion of the unity of the two types of laws, see Osman Bakar, Tawhid and Science: Islamic Perspectives on Religion and Science (Shah Alam, Malaysia: ARAH Publications, 2008), 70-72.

10. For a discussion of the human family as a cultural species with several subspecies and the family institution as the most fundamental and also the most important pillar of human civilisation, see Osman Bakar, 'Family values, the family institution and the challenges of the twenty-first century: An Islamic perspective,' Islam and Civilisational Renewal, vol. 3, no. 1 (October 2011), 12-36.

11. The idea of global Islamic civilisation as having major branches is based on ethnic considerations of which language is viewed as the most important. Each branch, which is basically a geo-cultural region, is identified with the dominant ethnic group and language in the region in question.

12. We have discussed the issue of identity of Malay-Islamic civilisation in several of our writings. See, for example, Osman Bakar, 'Islam and the Malay civilisational identity: tension and harmony between ethnicity and religiosity,' John Donohue and John Esposito, eds., Islam in Transition: Muslim Perspectives (New YorkOxford: Oxford University Press, 2007), 480-487; Osman Bakar, 'Islam dalam jati diri tamadun Melayu: konflik dan keharmonian antara tuntutan keetnikan dan keagamaan,' Kalthum Ibrahim, Farid Mat Zain, Nasruddin Yunos dan Ezad Azraai Jamsari, eds., Dunia Melayu dan Islam (Bangi: ATMA, UKM, 2009), 389-398; and Osman Bakar, 'Islam as a shaping force of cultural identity in Southeast Asia: the case of the Malay-Islamic identity,' a paper presented at the International Conference on Islam in Asia organised by School of Humanities and Social Sciences, Al Akhawayn University, Morocco held at Ifrane on 19-21 June 2013 (to be published).

13. The Qur'an asserts that the purpose of human existence is the worship of God ('ubudiyyah): "I have not created the jinn and human species except that they may worship Me," (surah 51, verse 56).

14. In contrast, modern secular Western civilisation is said to be based on the forgetting of God.

15. The Qur'an describes the comprehensiveness of man's state of remembrance of God as signified by his varied postures as follows: "Those who remember God standing, sitting, and lying down on their sides, and contemplate the [wonders] of creation in the heavens and the earth..." (surah 3, verse 191).

16. The Qur'an, surah 57, verse 20.

17. The common theology was Ash'arism, the common law Shafi'i school of jurisprudence, the common political system the sultanate, and the lingua franca the Malay language.

18. The Qur'an, surah 2, verse 143.

19. The Qur'an, surah 103.

20. For a detailed discussion of the issue of Islamicity of things, see Osman Bakar, Tawhid and Science, Introduction, xvii - xliv.

21. Seyyed Hossein Nasr, An Introduction to Islamic Cosmological Doctrines (Boulder: Shambala, 1978 edition), 4. 
22. Seyyed Hossein Nasr, 5.

23. See Osman Bakar, Islam and Civilisational Dialogue: The Quest for a Truly Universal Civilisation (Kuala Lumpur: University of Malaya Press, 1997), 9.

24. A science of civilisation that is truly universal in nature and comprehensive in scope was first developed in Islam. Al-Farabi (258 A. H./870 A.D. - 339 A. H./950 A. D.) may be regarded as the first scholar in the world to have explained in detail the subject-matter and the scope of this science, which he called al- ilm al-madanī. See his Ihssā'al- 'Ulüm ("Enumeration of the Sciences"), ed. 'Uthman Amin (Cairo: Dar al-Fikr al-'Arabi, 1949). We did not really have another serious attempt at formulating a new science of civilisation until Ibn Khaldun (1332 A. D. -1406 A. D.) introduced the term 'ilm al- 'umrān to signify this new science. For Ibn Khaldun's treatment of this new science, see his The Muqaddimah: An Introduction to History, trans. Franz Rosenthal (London and Henley: Routledge \& Kegan Paul, 1986), vol. 1. For an in-depth study in the English language of Ibn Khaldun's 'ilm al- 'umrān, see Muhsin Mahdi, Ibn Khaldun's Philosophy of History (Chicago: The University of Chicago Press, 1964, first Phoenix Press). Mahdi, however, translated 'ilm al- 'umrān as "science of culture."

25. I have dealt in great details with these themes of epistemology in Islam in my book, Classification of Knowledge in Islam (Kuala Lumpur: Institute for Policy Studies, 1992); also reprints (Cambridge, UK: The Islamic Texts Society, 1998); (Lahore: Suhayl Academy, 1998); and (Kuala Lumpur: ISTAC, IIUM, 2006). I treated in this book the epistemologies of al-Farabi, al-Ghazzali (450 A. H./1058 A. D. -505 A. H./1111 A. D.), and Qutb al-Din al-Shirazi (634 A. H./1236 A. D. -710 A. H./1311 A. D.), particularly on their respective classifications of the sciences (taqsīm al- ulūm).

26. For a detailed discussion of the idea of marātib al- ulüm in traditional Islamic epistemology, see Osman Bakar, Classification of Knowledge in Islam, especially chapters 2, 3 and 4 .

27. By cerebral knowledge is meant knowledge that is acquired by the brain through its cognitive power and processes.

28. By cardiac knowledge is meant knowledge that is acquired by the spiritual heart through its direct perceptions without having to depend on other cognitive instruments. 